\title{
Gulf States' Humanitarian Assistance for Syrian Refugees in Lebanon
}

- Susanne Schmelter -

\begin{abstract}
The humanitarian engagement of Gulf States has globally increased over the last two decades. This trend also manifests itself in Lebanon, where the displacement from Syria has lead to an unprecedented growth of Lebanon's diverse humanitarian sector. Due to the weakness of state institutions and the absence of a concerted government strategy, UN-institutions took a leading role in the coordination of international and local NGOs. However, numerous Gulf-funded organisations function largely outside the UN-coordinated response and rely on their own coordination structures. This paper explores these structures and characteristics of humanitarian assistance for Syrians displaced in Lebanon running primarily on Gulf funding. Thereby it focuses particularly on two umbrella organisations, URDA and I'tilaf, that are largely Gulf-funded and coordinate the work of numerous faith-based humanitarian organisations. Based on ethnographic field research - which was mainly conducted in 2014 and 2016 - the paper examines positions and negotiations within these humanitarian structures. These ethnographic insights are completed by an analysis of the available data and literature on Islamic charitable giving and funding trends in Lebanon. Coordination among the different humanitarian actors has repeatedly been a matter of complaint and discussion in both interviews and international reports: The lack of comprehensive coordination structures, the subsequent inefficiency in the use of funds, and the unsatisfying inclusion of local stakeholders are among the main points of critique. Here, Gulf-funded humanitarian assistance for Syrian refugees in Lebanon shows alternative models and approaches in regard to operating standards, administrative procedures, planning, reporting, and contact to the local population. Yet, ad hoc deliveries with few administrative procedures and a lack of transparency simultaneously expose the Gulf donors also to accusations of the misuse of funds and diminish accountability towards donors, beneficiaries and possible cooperation partners. This, finally, raises questions regarding the possibilities of the multilateral system to provide forums for exchange, efficient coordination, and mediation between conflicting positions.
\end{abstract}

Keywords: Syrian Displacement, Lebanon, Humanitarianism, Coordination structures, Gulf donors, Islamic Charities 


\section{Introduction}

The "Al-Awda model camp productive village" in the municipality of Bar Elias, Bekaa Valley, is surrounded by fields with a view of the mountain range that separates Lebanon and Syria. The camp was built in 2013 by the Union of Relief and Development Associations (URDA) to provide shelter for refugees from Syria. A sign at the camp's entrance displays the names and logos of 22 organisations that support the camp: among the first are Qatar Charity, Rahma International (Kuwait), RAF (Foundation Sheikh Thani bin Abdullah for Humanitarian Services, Qatar), etc. - Oxfam and the International Rescue Committee are the only western organisations. URDA receives most of its funding from the Gulf States, and as an umbrella organisation, it coordinates the work of around 100 member associations. URDA also implements its own shelter and health care programmes. The shelter site is quite exceptional, given that the Lebanese government usually strictly opposes the formal establishment of new refugee camps. URDA, however, is legally not in the same position as United Nation High Commissioner for Refugees (UNHCR) that usually negotiates Memoranda of Understanding with the host government.

The international humanitarian engagement of Gulf States has globally increased over the last two decades. ${ }^{1}$ This trend manifests itself also in Lebanon, where more than a million Syrian refugees are registered with the UNHCR. The war in Syria has caused the biggest refugee crisis since the Second World War and has boosted the presence of humanitarian actors throughout the region. One in four persons in Lebanon is believed to be a refugee from Syria. ${ }^{2}$ The Lebanese society is still deeply fragmented along the fault lines of its Civil War (1975-1990) and the sectarian proportional electoral system favours politics of patronage and clientelism. Since 2011, these predominantly Sunni Syrian refugees arrived in a state still deeply divided along confessional lines. These divisions continue to solidify due to the conflict in Syria and are reinforced by the regional alliances the Lebanese political parties maintain and heavily depend on. This has created a governmental paralysis in which state institutions fail to deliver adequate services to their citizens and to develop a comprehensive strategy of dealing with the displaced from Syria. ${ }^{4}$

\footnotetext{
${ }^{1}$ Andrea Binder, Claudia Meier, and Julia Steets, "Humanitarian Assistance: Truly Universal? A Mapping Study of Non-Western Donors," Website, Global Public Policy Institute, 2010, Vol. 12, available at: http://www.gppi.net/fileadmin/user_upload/media/pub/2010/Binder_Meier_Steets_2010_Truly_Universal_-_ Mapping_Study._GPPi_RP_12.pdf [last accessed 11 May 2017].

${ }^{2}$ At the time of writing (2017), around a million Syrian refugees in Lebanon are registered at UNHCR. See: UNHCR, "Lebanon," Website, Syria Regional Refugee Response Inter-agency Information Sharing Portal, 30 June 2017, available at: http://data.unhcr.org/syrianrefugees/country.php?id=122 [last accessed 11 March 2017]. The government does not adhere to the 1951 Geneva Convention for refugees and does not provide a comparable asylum legislation. An additional 500,000 Syrians are estimated to live without refugee registration and partly on the basis of a sponsorship system in Lebanon. See: Bassam Khawaja, "Lebanon Policy Leaves 'Second-Class' Syrians Vulnerable to Return: HRW," News Deeply, 14 March 2017, available at: https:/www.newsdeeply.com/syria/community/2017/03/14/lebanon-policy-leaves-second-class-syrians-vulnerab le-to-return-hrw-2 [last accessed 11 May 2017].

${ }^{3}$ Stephan Rosiny, “A Quarter Century of 'Transitory Power-Sharing'. Lebanon's Unfulfilled Ta'if Agreement of 1989 Revisited," Civil Wars, Abingdon, Taylor \& Francis, 2015, Vol. 17 (4), p. 485-502.

${ }^{4}$ Karim El Mufti, "Official Response to the Syrian Refugee Crisis in Lebanon, the Disastrous Policy of No-Policy," Civil Society Knowledge Centre, 2014, available at: http://
} 
The diverse Lebanese civil society is very active and experienced in dealing with conflict and displacement. This experience includes traditions of hosting and accommodating displaced persons as well as interactions with international and regional donors for development projects (e.g. concerning Palestinian refugees in Lebanon) and humanitarian programmes (after the July war in 2006/2007 and with Iraqi displacement). ${ }^{5}$ The polarised political environment, along with the laissez-faire approach of the Lebanese government, facilitates the development of different humanitarian approaches and coordination mechanisms. While the UN took a leading role in coordinating international and local NGOs responding to the displacement, numerous Gulf-funded, often Islamic, organisations work largely outside of the UN-coordinated efforts and have established their own coordination structures.

This paper explores these structures and characteristics of mainly Gulf-funded humanitarian assistance for displaced Syrians into Lebanon. It focuses particularly on two umbrella organisations: The Union of Relief and Development Associations (URDA; Arabic short: Itihad) and (for the sake of comparison in this paper) I'tilaf al-Majmuat al-Khairiya (The Alliance of Charitable Associations; Arabic short: I'tilaf). Employing an ethnographic research approach, about 20 semi-structured interviews with individuals working for and with these organisations, as well as field visits, were conducted in 2014 and 2016. Inspired by the methodological approach of the ethnographic regime analysis, ${ }^{6}$ this research focuses on positions and negotiations among different actors. In addition to studies and relevant documents, it strongly builds on statements and positions of persons with connections to Gulf-funded humanitarian engagement or Islamic charities working in assistance to Syrian refugees in Lebanon. As the main research interest revolves around the organisational structures, the paper focuses mainly on representatives and policy frameworks of these organisations and includes the recipients' perspective only occasionally. Exploring the recipients' perspective closer was also in practical regards difficult as, for example, opportunities to conduct "independent" interviews with refugees in the URDA run camps were limited. While the main interest lies in operating modes, programmes, and discourses on coordination, matters of representation and perception also influence stances and positions. Thus, also the question of the terminology impacted the research framing, as some of the interviewees deemed the terms Islamic charities or Gulf-funded organisations not necessarily appropriate for their work. Sensitive connotations of these terms are no surprise given that Lebanese politics revolve largely around a fragile sectarian balance with high dependencies on external funding, much of it coming from Gulf States. Moreover, the representation and positioning within Lebanon's humanitarian sector influence funding logic and possible cooperation.

civilsociety-centre.org/paper/official-response-syrian-refugee-crisis-lebanon-disastrous-policy-no-policy [last accessed 11 May 2017].

${ }^{5}$ Estella Carpi, “The Everyday Experience of Humanitarianism in Akkar Villages," Civil Society Knowledge Centre, 2014, available at:

http://civilsociety-centre.org/paper/everyday-experience-humanitarianism-akkar-villages [last accessed 11 May 2017].

${ }^{6}$ Sabine Hess and Vassilis Tsianos, "Ethnographische Grenzregimeanalyse," in Sabine Hess and Bernd Kasparek (eds.), Grenzregime: Diskurse, Praktiken, Institutionen in Europa, Berlin, Assoziation A, 2010, p. $243-264$. 
The paper begins with background information on the history, motives, and particularities of humanitarian donorship from the Gulf. It then presents the two umbrella organisations (URDA and I'tilaf) and discusses to what extent descriptions like "Islamic charities" or "Gulf-financed" are accurate. URDA has been able to significantly expand its programmes and even runs several shelter sites across the country. The following section takes a closer look on their organisation and their positioning in the Lebanese policy framework. While URDA has been able to establish working agreements and some form of cooperation, an analysis of statements by representatives of URDA and I'tilaf, as well as a few of their member organisations in coordination with the UN-led system, underlines the impression that the systems run in parallel rather than in close cooperation. The conclusion reflects on how the Lebanese "laboratory" has been operating and how studying it can contribute to reforms of the international humanitarian system.

\section{Gulf-financed International Humanitarian Assistance}

The plurality of humanitarian actors and the presence of Gulf-financed NGOs in Lebanon reflect a global trend of so-called "emerging", or "non-Western" donors engaging internationally in humanitarian assistance. The four most important donor states from the Gulf - Saudi Arabia, United Arab Emirates (UAE), Kuwait, and Qatar - share several commonalities: they are conservative monarchies, they have an Arab-Sunni identity, and their economic wealth is based on oil and gas resources. In the 2000s, they engaged in fiscal support of Palestine, Pakistan, Afghanistan, and in the reconstruction of Lebanon after the Israeli war on Lebanon in July 2006; they channelled their funds bilaterally from government to government, as well as multilaterally via international organisations. ${ }^{10}$ Taking into account the humanitarian emergencies in the Middle East, funding by Gulf States has risen sharply. In 2015, contributions reached almost 2.4 billion US dollars, which resulted in an almost $500 \%$ increase of their contributions since 2011. ${ }^{11}$ Yet, these amounts of humanitarian spending are only estimations, which are based on the data of the Financial Tracking Service (FTS). The FTS, run by the Office for the Coordination of Humanitarian Affairs (OCHA), tracks the flow of international humanitarian funds. Yet, it accounts for only a part of the international humanitarian spending, as data sharing with the FTS is not obligatory and is handled differently by the Gulf States donors. ${ }^{12}$ The United Arab Emirates is the only Arab state in the

\footnotetext{
${ }^{7}$ Alain Robyns and Véronique de Geoffroy, “Les Bailleurs Emergents de l'Aide Humanitaire. Le Cas des Pays du Golfe," Plaisians, Groupe URD, 2009, available at:

http://www.urd.org/IMG/pdf/09 1010 nouveaux bailleurs VF.pdf [last accessed 11 May 2017].

${ }^{8}$ Andrea Binder, Claudia Meier, and Julia Steets, op. cit., p. 4.

${ }^{9}$ Céline Billat, "The Funding of Humanitarian Action by the Gulf States: A Long-Term Commitment," Humanitarian Aid on the Move, Plaisians, Groupe URD, 2016, Vol. 17, p. 15-19, available at: http://www.urd.org/The-funding-of-humanitarian-action [last accessed 11 May 2017].

${ }^{10}$ Andrea Binder and Claudia Meier, "Opportunity Knocks: Why Non-Western Donors Enter Humanitarianism and How to Make the Best of It," International Review of the Red Cross, Geneva, International Committee of the Red Cross and Cambridge University Press, 2011, Vol. 93 (884), p. 1142, 1143.

${ }^{11}$ Development Initiatives, "Global Humanitarian Assistance Report 2016," Global Humanitarian Assistance, Bristol, Development Initiatives Ltd, 2016, p. 44, available at: http://devinit.org/post/global-humanitarian-assistance-report-2016/\# [last accessed 11 May 2017]. ${ }^{12}$ Alain Robyns and Véronique de Geoffroy, op. cit., p. 9.
} 
Donor Support Group, an advisory council to the OCHA, and usually reports funding accurately. Funding from Qatar, by contrast, is not as transparent. Kuwait, however, gained international recognition by organising three large donor conferences for the UN. In Saudi Arabia, the royal house regularly organises public donation campaigns that allow a quick mobilisation of funds. ${ }^{13}$ Looking at the FTS data of humanitarian engagement of the Gulf States in Lebanon, the financial contributions of Kuwait, Saudi Arabia, UAE, and Qatar show strong fluctuations from year to year. Nevertheless, they range among the top 21 humanitarian donors for Lebanon in the years 2011-2014.

While this increase of international humanitarian engagement, and maybe also the introduction of a global tracking system for humanitarian funds in 2000, has lead to their labelling as emerging donors, Gulf States international humanitarian engagement goes further back in time: Throughout the 1970s and '80s, for example, Saudi Arabia financed humanitarian programmes in Africa and South Asia. ${ }^{15}$ Despite histories and traditions of international humanitarian engagement, the Gulf States, along with the BRICS states (Brazil, Russia, India, China, South Africa), are often described as "emerging donors." This refers to the international system of institutions established after the Second World War: the Organisation for Economic Co-operation and Development (OECD) founded in 1960/1961 the Development Assistance Council (DAC) which has 28 member states, ranging from the Americas and Europe to the Pacific region. These DAC states today dominate UN institutions and have agreed upon common directives and control councils. The so-called emerging donors do not feel bound to these directives and are thus - at least in the short term - able to provide "direct" and less bureaucratic assistance. ${ }^{16}$ Compared to the DAC-states, the Gulf donors also do significantly fewer evaluations and less reporting on their humanitarian programmes. They are more flexible with implementing institutions on the ground, which tends to favour local ownership over crisis responses. Furthermore, their donations impose less binding conditions, such as governance agreements, democratisation, women's rights, etc. As this respects the sovereignty of the receiving countries, it might also squander

\footnotetext{
${ }^{13}$ Ibid.; Susanne Schmelter and Ann-Kathrin Seidel, "Sanitäter Mit Scheckbuch," Zenith, Berlin, Deutscher Levante Verlag, 2015, p. 78-83; Khalid Al Yahya and Nathalie Fustier, "Saudi Arabia as a Humanitarian Donor: High Potential, Little Institutionalization,” Berlin, Global Public Policy Institute, 2011, Vol. 14, available at: http://www.gppi.net/fileadmin/user_upload/media/pub/2011/al-yahya-fustier_2011_saudi-arabia-as-humanitarian -donor_gppi.pdf [last accessed 11 May 2017].

${ }^{14}$ Financial Tracking System, "Funding to Syrian Crisis 2015," Website, Financial Tracking System, 2015, available at: https://ftsarchive.unocha.org/pageloader.aspx?page=special-syriancrisis\&year=2015 [last accessed 11 May 2017]. See also: Susanne Schmelter and Ann-Kathrin Seidel, op. cit.

${ }^{15}$ Sultan Barakat and Steven Zyck, "Gulf State Assistance to Conflict-Affected Environments," Kuwait Programme on Development, Governance and Globalisation in the Gulf States, London, The Centre for the Study of Global Governance, 2010, p. 7-9, available at: http://eprints.lse.ac.uk/55240/ [last accessed 11 May 2017]; Leo Barasi, “Saudi Arabia’s Humanitarian Aid a Political Takeover?”, Humanitarian Exchange, London, Humanitarian Practice Network, 2005, Vol. 29, available at: http://odihpn.org/magazine/saudi-arabia\%C2\%92s-humanitarian-aid-a-political-takeover/ [last accessed 11 May 2017].

${ }^{16}$ Andrea Binder, “Geben Ist Außenpolitik,” Welternaehrung, Bonn, Zeitung Welthungerhilfe, 2014, available at: https://www.welthungerhilfe.de/fileadmin/user_upload/Mediathek/Welternaehrung/Welternaehrung-Zeitung-We lthungerhilfe-2-2014.pdf [last accessed 11 march 2017].
} 
opportunities to exert influence. ${ }^{17}$

Analysing the humanitarian engagement of Gulf States in conflict zones like Bosnia-Herzegovina, Afghanistan, Iraq, Lebanon, and the occupied Palestinian territories, Sultan Barakat and Steven Zyck describe three main motives. The first is to support stability in and around regions of conflict and enhancing diplomatic relations, "diplomatic" referring to the public perception of the affected communities. The second motive is solidarity with the Palestinian cause, whereby humanitarian engagement also appears as a compensation for failures to take effective political or military action. The last motive stems from genuine humanitarian concerns with strong roots in Islamic traditions. One of the five pillars of Islam is the religious duty of giving zakat. It requires Muslims to give around 2.5 percent of one's wealth to the poor and those in need of support. These include in particular orphans, widows, prisoners, unemployed, homeless, victims of natural disasters, and persons in need of medicinal treatment. ${ }^{18}$ Besides practical regulations regarding the amount and the time of giving zakat, the attitude is also considered important: Zakat has the function of reducing social injustice and is informed by a sense of solidarity rather than simple charity. Those giving are supposed to be trusting of and respectful towards the recipients of zakat. Other forms of charitable giving include sadaqa, voluntary donations, and waqf, religious foundations that fund religious institutions and other public services. The opinions of whether Muslims should be prioritised as recipients of zakat differ: while it was traditionally more common to help Muslims and persons in the closer environment, the necessity to help all persons in need, indiscriminately of religion, is today widely regarded a necessity. The latter viewpoint has been adopted by most internationally acting (Islamic) humanitarian organisations.

Relatively low standards of control and supervision, as well as the limited international possibilities to document the flow of humanitarian funds, make it almost impossible to systematically track and map the humanitarian funding from Gulf donors. ${ }^{20}$ While the governments' donations are difficult to track, those of non-state actors, such as private persons and foundations transferring significant sums of humanitarian funds abroad, remain even more opaque. ${ }^{21}$ This was reflected in explorative interviews in the Bekaa Valley in November 2015. One Sheikh and NGO director who cooperates with local Islamic charities that receive funding from the Gulf commented: "Besides the official state donations, there are also private donors. But they don't want to talk about this ... Better you do research on something else; it would be a pity if you do all this work and after you can only write two pages. ${ }^{22}$ This difficulty to gain any information about unmonitored funding was also confirmed by a journalist investigating this topic on Lebanon and on the donor side in Qatar. ${ }^{23}$

\footnotetext{
${ }^{17}$ Sultan Barakat and Steven Zyck, op. cit., p. 33-37.

${ }^{18}$ Jonathan Benthall and Jérôme Bellion-Jourdan, The Charitable Crescent: Politics of Aid in the Muslim World, New York, I.B. Tauris, 2003, p. 10.

${ }^{19}$ Ibid.

${ }^{20}$ Sultan Barakat and Steven Zyck, op. cit., p. 7.

${ }^{21}$ Sultan Barakat and Steven Zyck, op. cit.

${ }^{22}$ Interview by the author with NGO director, Bekaa Valley, 5 December 2015.

${ }^{23}$ Conversation between the author and a journalist working in the field, Bekaa Valley, 5 December 2015.
} 


\section{The Umbrella Organisations: URDA and I'tilaf}

The fact that the majority of refugees from Syria are Sunnis, ${ }^{24}$ reflects also in the increased presence of Sunni charities. Most of URDA's and I'tilaf member associations feature typical Islamic charitable programmes, such as support to orphans and women-headed households, and distributions during Ramadan and Eid al-Fitr at the end of the fasting month. While these charities receive their funding mainly from the Gulf, Islamic humanitarian organisations and Gulf donorship are not necessarily interrelated and each has specific backgrounds and implications. For example, the UK-based international NGO Islamic Relief, operating in Lebanon and coordinating closely with the UN-led response, promotes the compatibility of international humanitarian standards with policies that are guided by Islamic values. ${ }^{25}$ In contrast, URDA and I'tilaf receive most of their funding from the Gulf; they have established their own coordination structures that function largely outside of the UN system, and they are also less clear in depicting their organisational profile. Studies suggest that I'tilaf is dominated by Salafi charities and that URDA is a charitable institution founded by the Muslim Brotherhood. ${ }^{26}$ Both the Muslim Brotherhood and the Salafis have started from the teachings of Islamic clerics in the beginning of the $20^{\text {th }}$ century and the end of the $19^{\text {th }}$ century, respectively, and have developed into transnational Islamic political movements. While the Muslim Brotherhood typically organises as a party placing a strong emphasis on charitable work and welfare, the Salafis are a rather loose movement whose branches place variable emphasis on political, military, and charitable work. ${ }^{27}$ Particularly in Northern Lebanon, the Salafis have a considerable base, although they are not organised as a political party. ${ }^{28}$ The Lebanese branch of the Muslim Brotherhood, which is called Islamic Group (Jamaa al-Islamiya) is a minor political party in Lebanon ${ }^{29}$ and is reported to have funded URDA..$^{30}$ Despite I'tilaf's and URDA's linkages to Islamic political movements, the accounts of the representatives of the two umbrella organisations seem quite careful about establishing

\footnotetext{
${ }^{24}$ International Crisis Group, "Too Close for Comfort: Syrians in Lebanon,” Middle East Report, Brussels, International Crisis Group, 2013, Vol. 141, p. 3-4, available at:

http:/www.crisisgroup.org/en/regions/middle-east-north-africa/egypt-syria-lebanon/lebanon/141-too-close-for-c omfort-syrians-in-lebanon.aspx [last accessed 11 May 2017].

${ }^{25}$ Interview by the author with the director of Islamic Relief Lebanon, Saida, 1 August 2016; Islamic Relief, Lebanon, Website, Islamic Relief, available at: http://www.islamic-relief.org/category/where-we-work/lebanon/ [last accessed 29 September 2017].

${ }^{26}$ Sarah Hasselbarth, Islamic Charities in the Syrian Context in Jordan and Lebanon, Beirut, Friedrich-Ebert-Stiftung, 2014.

${ }^{27}$ Gilles Kepel, Das Schwarzbuch des Dschihad: Aufstieg und Niedergang des Islamismus, München, Piper, 2002.

${ }^{28}$ Hashem Osseiran, “Lebanon's Salafists Poised for Parliamentary Polls?”, Website, The Arab Weekly, 27 November 2016, available at: http://www.thearabweekly.com//Opinion/7141/Lebanon's-Salafists-poised-for-parliamentary-polls? [last accessed 11 May 2017].

${ }^{29}$ Raphaël Lefèvre, “A New Direction for Lebanon's Muslim Brothers,” Blog, Diwan Middle East Insights From Carnegie, 2 November 2016, available at: http://carnegie-mec.org/diwan/62740?lang=en [last accessed 29 September 2019].

${ }^{30}$ Abd el-Rahman Arabi, "Iikhawan' lubnan yantakhibun murshdhm... alkalimat lilshuyukh 'am lilshabab?", Website, Alaraby, 20 December 2015, available at: https:/www.alaraby.co.uk/politics/2015/12/19/ [last accessed 11 May 2017].
} 
such connections.

The following section seeks to outline the organisational profile of I'tilaf and URDA; it provides basic information on the size and outreach of the organisations, as well as their positioning in regard to Islamic charitable work, and their funding sources. Gathering information on these organisations proved to be quite challenging: both were newly established in 2012 and have hardly been subjected to third-party investigations. Moreover, they barely publish any reports that contain transparent data on financial matters in general. Therefore, the insights discussed below stem mainly from interviews and information material provided by I'tilaf and URDA.

I'tilaf ${ }^{31}$ is the smaller of the two coordination networks. The organisation's office is located in the city of Halba, in the northern governorate of Akkar, and has only very basic equipment. It has very little published material, no website, and almost no printed material that would help inform about I'tilaf's work, although they have created a Facebook page. The director, Sheikh Loqman Khodr, comes from Akkar and has been involved in providing support to displaced Syrians since the beginning of the conflict in 2011. He speaks about I'tilaf's development and its projects. I'tilaf is mainly active in northern Lebanon and has around 20 member organisations. Almost all of them were already active in Lebanon before 2011, working, for example, with schools and hospitals. Sheikh Loqman recalls how the local population received arriving refugees and how the initially large sums of funds dried out in recent years:

"From 2011 to 2013 there was a lot of money coming and we could do many projects with the organisations that we trust on the ground. Many of them were very strong; they did not only have money available but also many volunteers (...). Then, in 2014-2016, the funding went down by $80 \%$." 32

I'tilaf's main donors come from Saudi Arabia, Qatar, Bahrain but also from within Lebanon and, from charitable organisations in western countries.

I'tilaf itself works mainly in relief activities by distributing staple goods and running a bakery (furn al-khair), and its work in the health sector includes the treatment of wounded persons coming from Syria. Through these projects, I'tilaf currently serves around 4000 beneficiaries. Young, single men are excluded from this as "they should be working." 34 According to Sheikh Loqman, the recent decrease of funding could also be due to the increase of emergencies in other countries like in Yemen, Iraq, Syria, and the situations in Turkey and Jordan, which demand constant funds. Even so, the modes of funding have changed for I'tilaf:

"We don't have anymore money to invest or to distribute. Everything comes now as in-kind donations and is channelled via associations... Even the bank accounts of some of the organisations were shut down. This is to better control the money and to prevent

\footnotetext{
${ }^{31}$ The information and quotes in this section rely, if not otherwise indicated, on an interview by the author with director of the I'tilaf, Sheikh Loqman Khodr, at his office in Halba, Akkar 18 August 2016.

${ }^{32}$ Interview by the author with Sheikh Loqman Khodr, at his office in Halba, Akkar 18 August 2016.

${ }^{33}$ As an example, Sheikh Loqman mentions the US-based charitable organisation Helping Hands.

${ }^{34}$ Interview by the author with Sheikh Loqman Khodr, at his office in Halba, Akkar 18 August 2016.
} 
that it is used for terrorism." 35

The accusation of funding terrorism is a recurring concern regarding how funds are used and channeled, and hard to disprove due to the lack of transparency and documentation. Moreover, the conception of humanitarian action in Islam and its role in a wider picture suggest that the solidarity, which is connected to charitable giving, also penetrates the political and military realms. While several studies provide a careful analysis of motives of the Islamic charity work and its context, ${ }^{36}$ others are more explicit about the possible linkages to militant projects. ${ }^{37}$ In regard to their work in Northern Lebanon where the border with Syria was very porous, Sheikh Loqman explains further:

"It happened that some organisations mixed humanitarian and military engagement. Our work, however, is strictly humanitarian and if we find out that someone does something else, we stop the cooperation. Now, we work according to our possibilities - we don't have a long-term plan and we don't have fixed employees. We work seasonally for example when the winter comes, during Ramadan and so on."38

Sheikh Loqman describes I'tilaf's mission as being guided by humanitarian concerns and religious beliefs, seeking to help everybody in need. A colleague of the Sheikh who works equally in the humanitarian field in Akkar explains later on: "The Muslim Brotherhood might appear moderate, modern, and open-minded, but they are organised as a party and they look if you belong to them or not - by contrary this is not the case with the Salafis who work with everyone." ${ }^{39}$ In this sense he, as well as Sheikh Loqman, talk of URDA as "the party" (hizb). I'tilaf does not coordinate with URDA and has a rather critical position to it: "The party" is described to be quite dominant by opening field offices across the country and controlling the work of its member organisations. I'tilaf by contrast avoids interfering in the work of its member organisations on the ground. "They have all regular registrations from the state and Dar el-Fatwa [a governmental institution in charge with rulings specific to Lebanon's Sunni community]," explains Sheikh Loqman. He adds, "We trust our member organisations that they know best what is needed on the ground, if we would interfere we might actually ruin their work. We basically coordinate to avoid the duplication of services." 40

URDA, the Union for Relief and Development, has expanded its activities rapidly since its establishment in 2012. Today, it has more than 100 humanitarian and development member associations that operate across the country. The majority of them display an Islamic (Sunni)

\footnotetext{
${ }^{35}$ Interview by the author with Sheikh Loqman Khodr, at his office in Halba, Akkar 18 August 2016.

${ }^{36}$ Jonathan Benthall and Jérôme Bellion-Jourdan, op. cit.; Mohammed Kroessin and Abdulfatah Mohamed,

"Saudi Arabian NGOs in Somalia: 'Wahabi' Da'wah or Humanitarian Aid?", in Gerard Clarke and Michael Jennings (eds.) Development, Civil Society and Faith-Based Organizations, London, Palgrave Macmillan, 2008, p. 187-213.

${ }^{37}$ Abdel-Rahman Ghandour, “L'humanitaire Au Service de L'islam,” Website, L'Express, 24 October 2002, available at: http://www.lexpress.fr/culture/livre/l-humanitaire-au-service-de-l-islam_818277.html [last accessed 11 May 2017].

${ }^{38}$ Interview by the author with Sheikh Loqman Khodr, at his office in Halba, Akkar 18 August 2016.

${ }^{39}$ Interview by the author with the director of the Lebanon branch office of the international charitable organisation IHH Humanitarian Relief Foundation, Akkar 18 August 2017.

${ }^{40}$ Interview by the author with Sheikh Loqman Khodr, at his office in Halba, Akkar 18 August 2016.
} 
orientation in their names and logos, but there are also secular organisations as members. These organisations work in different sectors such as relief, development (e.g. livelihood and microfinance programmes, vocational training, bakeries), shelter, healthcare, sponsorships (e.g. as monthly support for orphans and chronic patients), psychosocial support, and education. ${ }^{41}$ The coordinating role of URDA often includes supervision and control. In the education sector, for example, the running of the schools and the teaching contents are the responsibility of the implementing member organisations. URDA, however, has a committee that supervises the schools, ensures certain criteria, and approves programmes of the member organisations and demands regular reports. ${ }^{42}$ In addition to that, URDA cooperates with a wide range of organisations and independently implements programmes in the sectors of health and shelter. A strong emphasis on "secondary healthcare" provides particularly support for treatment and medication costs that are not covered by UNHCR.

URDA's main office is located in Hamra, west Beirut. Around 40 employees work in office rooms that have a new and modern set up, with a calligraphic design at the wall in the public relations department. ${ }^{43}$ In contrast to I'tilaf or also Islamic Relief, URDA representatives are very explicit about not being called an "Islamic" organisation, even though the majority of their member associations display a Sunni Islamic profile. An URDA representative explains, "We are not an Islamic organisation, we provide certain services simply because the big majority of refugees from Syria are Muslim. If they would be Christians we would build them a church, if they would be Jews we would build them a synagogue," and adds that URDA receives funding "not because of doing Islamic charity activities, but because of our mediating role that enables coordination between international, regional, and local organisations." 44

Also URDA's director Sheikh Hosam al-Ghali highlights, "We are open for every initiative that wants to work with us," and that their aim is to serve everybody in need, "regardless which ethnic or political background the person has." ${ }^{\text {" }}$ URDA places a particular emphasis on widows who have to take care of their families and orphans in its programming. It counts over 800,000 beneficiaries in 2015 .

URDA receives funding from a wide range of donors, mainly from the Gulf, whereby Qatar seems to be the main donor country. According to a list provided by URDA in 2014 the organisation receives 70 percent of its funds from the Gulf States: between 2012 and 2014, it received nearly 14 million US dollars of bilateral funds, which were not channelled through the UN system. The NGO Qatar Charity as the main donor granted 4.5 million US dollars; four Kuwaiti donors gave a total of six million US dollars; twelve other regional donors donated amounts from 200,000 to 1.5 million US dollars. Among the Western donor

\footnotetext{
${ }^{41}$ See: Union of Relief and Development Associations, "Members and Partners," Website, URDA Union of Relief \& Development Associations, available at: http://urda.org.lb/members.aspx [last accessed 29 September 2017].

${ }^{42}$ Telephone interview by the author with URDA official in Beirut, 5 September 2016.

${ }^{43}$ Interview by the author, URDA office, Beirut, 02 August 2016.

${ }^{44}$ Telephone interview by the author with URDA official in Beirut, 5 September 2016;

${ }^{45}$ Quotes in Susanne Schmelter and Ann-Kathrin Seidel, op. cit.

${ }^{46}$ URDA in Lebanon, "Annual Report of the Achievements of URDA - Lebanon. A Comprehensive

Humanitarian Response,” Beirut, URDA, 2015.
} 
organisations are only mentioned the Danish Red Crescent and Human Care, an Australian prosthesis producer. URDA uses the humanitarian funds immediately and directly on the ground, reassures director Sheikh Hosam Ghali. The administrative council, which consists of twelve department managers, is responsible for the other 90 percent and Sheikh Ghali himself administers 10 percent for fast emergency relief. ${ }^{47}$ URDA holds an annual conference in Turkey that provides a forum to exchange, market, acquire funds, and formulate advocacy goals.

As umbrella organisations I'tilaf and URDA seek to integrate and coordinate the work of a variety of member associations and also negotiate their positioning towards the international system. Despite a lack of comprehensive overviews on the funding situations of URDA and I'tilaf, the available data strongly suggests that they are largely driven by Gulf funds. Examining the work of URDA and I'tilaf might thus provides insights into what kind of relief mechanisms are fostered by Gulf donors in Lebanon and how these examples relate to wider, global dynamics of humanitarian donorship from the Gulf.

\section{Lebanese Context and Camps}

The Lebanese Civil War (1975-1990) has deepened societal and political divisions. Even today, the country's political system is not only organised along a sectarian proportional election system but also along regional alliances which support and finance the respective parties and pursue their interests in Lebanon. This reflects also on the welfare sector ${ }^{48}$ as well as in current and previous emergency relief programmes. In the aftermath of the Israeli war in July 2006, donors from the Gulf financed the reconstruction more generously, faster and efficiently than Western donors. At the time, Iran was also a prominent donor and channelled its funds mainly through the militant and Iran-backed Shi'a party, Hizbollah, ${ }^{49}$ while the donor states Saudi Arabia, Kuwait, and Qatar channelled their funds via government institutions and local organisations. Thus, Iran and the Gulf donors channelled their funds in accordance with their alliances with Lebanon's political parties. Thereby, they also joined a competition revolving around the ideological rationale of who is providing the best support and backup for the Lebanese population affected by the war.

The support for Syrian refugees happens against the backdrop of other ideological stakes. In

\footnotetext{
${ }^{47}$ Susanne Schmelter and Ann-Kathrin Seidel, op. cit.

${ }^{48}$ Melani Claire Cammett, Compassionate Communalism: Welfare and Sectarianism in Lebanon, Ithaca, Cornell University Press, 2014.

${ }^{49}$ On Hizbollah as a provider of emergency relief see: Mona Harb, "Faith-Based Organizations as Effective Development Partners? Hezbollah and Post-War Reconstruction in Lebanon," in Gerard Clarke and Michael Jennings (eds.), Development, Civil Society and Faith-Based Organizations, Basingstoke, Palgrave Macmillan, 2008, p. 214-239, available at: http://link.springer.com/chapter/10.1057/9780230371262_10 [last accessed 11 May 2017]; Estella Carpi, "Politics of Care and Social Responses in the July 2006 War: A Special Focus on Local Faith-Based Organisations," Civil Society Knowledge Centre, 2016, available at: http://civilsociety-centre.org/paper/politics-care-and-social-responses-july-2006-war-special-focus-local-faith-ba sed-organisations [last accessed 11 May 2017].

${ }^{50}$ Christine Hamieh and Roger Mac Ginty, "A Very Political Reconstruction: Governance and Reconstruction in Lebanon after the 2006 War," Disasters, Hoboken, Wiley-Blackwell for the Overseas Development Institute, 2010, Vol. 34, p. 103-123; Sultan Barakat and Steven Zyck, op. cit.
} 
2005, the so-called Cedar Revolution led to the withdrawal of the Syrian occupying forces. These events gave rise to an alliance of political parties known as the 14 March Alliance. Having felt oppressed by the Syrian occupation for almost 40 years, the movement's parties could easily generate a sense of solidarity with the cause of the displaced Syrians, who mainly fled the regime's repression. Internally, the 14 March movement is opposed by the parties of the 8 March Alliance, which supports the Syrian regime and is dominated by Hizbollah. With Hizbollah, the Assad regime has a strong and loyal ally in Lebanon's society and political system. While Iran and Hizbollah are among the Syrian regime's most important allies, the Gulf States oppose the Syrian regime and its regional alliances. ${ }^{51}$ As regional powers are aligned with the Lebanese parties, the Syrian conflict has fuelled and catalysed tensions in Lebanon. Hizbollah has been openly fighting on the side of the Syrian army since May 2013 and has significantly altered the power balance inside Syria.

The course of the war in Syria directly impacts the political dynamics in Lebanon. The threat of Sunni extremism that became virulent through the offences by Da'esh in 2014, for example, has triggered more security cooperation between Hizbollah and members of the March 14 movement with their respective international allies in establishing new security plans and securing the Syrian-Lebanese border. ${ }^{53}$ Since the beginning of 2015 new visa and residence regulations ${ }^{54}$ led to the majority of Syrians in Lebanon to lose their regular residency status and access to basic rights. ${ }^{55}$ On the $31^{\text {st }}$ of October, 2016, Lebanon's 29-month-long political vacuum was resolved with the election of Michel Aoun as president, who also was Hizbollah's preferred candidate. This happened while the Syrian regime and its allies, among them Hizbollah, militarily won the battle of Aleppo.

In this geopolitical context and against the background of the government's specific shelter policies, URDA has established its own relations within the Lebanese political landscape. The

\footnotetext{
${ }^{51}$ Erik Mohns and André Bank, "Syrian Revolt Fallout: End of the Resistance Axis?”, Middle East Policy, Hoboken, Wiley-Blackwell, 2012, Vol. 19 (3), p. 15-25.

${ }^{52}$ International Crisis Group, “Lebanon's Self-Defeating Survival Strategies," Middle East Report, Brussels, International Crisis Group, 2015, Vol. 160, available at: http:/www.crisisgroup.org/en/regions/middle-east-north-africa/syria-lebanon/lebanon/160-lebanon-s-self-defeati ng-survival-strategies.aspx [last accessed 11 May 2017].

${ }^{53}$ Aaron Zelin, "Jihadism in Lebanon after the Syrian Uprising," in Maximilian Felsch and Martin Wählisch (eds.), Lebanon and the Arab Uprisings: In the Eye of the Hurricane, New York, Routledge, 2016, p. 50-69. ${ }^{54}$ Lebanon Support, "Formal Informality, Brokering Mechanisms, and Illegality. The Impact of the Lebanese State's Policies on Syrian Refugees' Daily Lives," Civil Society Knowledge Centre, 2016, available at: http://civilsociety-centre.org/resource/formal-informality-brokering-mechanisms-and-illegality-impact-lebanesestate $\%$ E2\%80\%99s-policies [last accessed 11 May 2017].

${ }^{55}$ Lebanon Support, "Syrian Refugees' Livelihoods. The impact of constraining legislations and increased informality on Syrians’ Daily Lives," Civil Society Knowledge Centre, 2016, available at: http://civilsociety-centre.org/resource/syrian-refugees-livelihoods-impact-progressively-constrained-legislationsand-increased [last accessed 11 May 2017]; Lebanon Support,“Access to Healthcare for Syrian Refugees. The Impact of Fragmented Service Provision on Syrians' Daily Lives," Civil Society Knowledge Centre, 2016, available at:

http://civilsociety-centre.org/resource/access-healthcare-syrian-refugees-impact-fragmented-service-provision-sy rians\%E2\%80\%99-daily-lives [last accessed 11 May 2017]; Bassam Khawaja, op. cit.

${ }^{56}$ International Crisis Group, "Hizbollah's Syria Conundrum," Middle East Report, Brussels, International Crisis Group, 2017, Vol. 175, available at: https://d2071andvip0wi.cloudfront.net/175-hizbollah-s-syria-conundrum.pdf [last accessed 11 May 2017].
} 
most outstanding aspect is probably that URDA has settled arrangements with Lebanese municipalities to formally establish camps for the refugees from Syria. Due to the experience with the Palestinian refugees and also in view of the labour market's requirements, the Lebanese government has generally not allowed the formal establishment of new camps for the refugees from Syria. ${ }^{57}$ Nevertheless, agglomerations of makeshift tents and huts have grown close to agricultural sides and villages across the country; often they have started from previous housing facilities of Syrian seasonal workers. These "informal tented settlements," as they are called in official jargon, are not centrally managed, and only after their set up do local and international organisations reach out to provide services such as sanitary facilities, support for rent, medical services, educational programmes, etc.

Countrywide, URDA runs 45 shelter sites encompassing apartment complexes, tent settlements, and so called "model productive villages." Agreements on the set-up of shelter sites are usually negotiated with local municipalities. The national government - that was from 2014 to 2016 without a president - accepts the settlements without officially approving them on a legal level. An official of URDA's PR department in Beirut explains:

"These agreements are good for both sides: for the refugees and for the local Lebanese population who appreciates that the refugee settlements are not coming up wildly close to their living areas. They are managed and well organised and projects as for example waste management bring benefits for both sides." 59

And concerning the state's non-camp policy he continues: "We are legally not in the same position as the UNHCR and we can work around these government regulations." ${ }^{60}$ Officially, the Lebanese government has the right to close down the camps at anytime, but, depending on the area, it is largely in favour of them. As the camps were planned, each of them has a uniform type of housing units, which stand in orderly rows and have access to regular electricity. Moreover, each of the URDA shelter sites is supervised by a director who is usually from outside the camp and Lebanese. "If we would take someone from inside the community, there would be a risk that when there are conflicts, he might give advantages to someone in the camp." 61 Beyond the provision of practical services, URDA officials emphasise the role of social cohesion and an intact community life in the camps.

In Ar-Rahman camp in Talabaya, ${ }^{62}$ for example, there are 140 tents that mainly house women headed families from Ghouta, rural Damascus in Syria. An URDA official at the camp explains: "Of course the people don't live anymore in their houses and in the same

\footnotetext{
${ }^{57}$ Lewis Turner, "Explaining the (Non-)Encampment of Syrian Refugees: Security, Class and the Labour Market in Lebanon and Jordan," Mediterranean Politics, Abingdon, Taylor \& Francis, 2015, Vol. 20, p. 1-19.

${ }^{58}$ AUB and UN Habitat, "No Place to Stay? Reflections on the Syrian Refugee Shelter Policy in Lebanon," Beirut, American University of Beirut and UN Habitat, 2015, available at: https://www.aub.edu.lb/ifi/publications/Documents/research_reports/20150907_noplacetostay.pdf [last accessed 11 May 2017]; Interview by the author with UNHCR shelter expert, Beirut, 22 July 2014.

${ }^{59}$ Interview by the author with URDA official, Beirut, 2 August 2016.

${ }^{60}$ Interview by the author, URDA office, Beirut, 2 August 2016.

${ }^{61}$ Interview by the author, URDA office, Beirut, 2 August 2016.

${ }^{62}$ Field visit by Ann-Kathrin Seidel and the author, November 2014; See also: Susanne Schmelter and Ann-Kathrin Seidel, op. cit.
} 
environment. But at least they find similar social structures (...)." URDA has also built a mosque and employs a sheikh, a person trained to give Islamic guidance, as camp director. Sheikh Khaled works in one of URDAs member organisations in the Bekaa, as camp director he is also the director of the camp's school and on Fridays he preaches in the camp's mosque.

In the school Syrian women volunteer as teachers, the curriculum follows the Syrian curriculum but replaced the Ba'thist secular national education by Islamic education. The school is financed by a Kuwaiti initiative and another poster in the camp highlights the donations of Qatar Charity. A widow and mother of twelve children who lives in the camp reports that these community structures also help her in looking for a husband for her daughter, as she finds it much more difficult to know about possible candidates in their Lebanese exile.

"Al-Awda productive village" ${ }^{63}$ lies also in the Bekaa Valley and is one of URDA's exemplary projects. The camp has 400 caravans and containers, and is the biggest URDA run "productive village." It has a medical centre, a mosque, and a market with a bakery, a butcher, a grocery store, and a tailor. It also has an education centre, which provides education programmes for children and vocational training for adults. URDA provides for shelter, electricity and medical services; other organisations contribute to the setup and maintenance of the camp. Promotional videos feature the names of the organisations and their contributions to the camp. ${ }^{64}$ In addition to the camp set-up, visits and lines of communication seem to be thoroughly organised: journalists and other visitors need to arrange their visits and rights to photograph via the office in Beirut. A separate and well-equipped container provides the possibility to stay overnight for visitors. Uncoordinated visits, specifically service deliveries of non-member organisations, are similarly not possible without prior consultation with the head office.

URDA employs the director and three security guards in al-Awda camp. The director has his office container in the camp's entrance area. He hails from the nearby village and his job involves communication with visitors, authorities and the URDA office, as well as social work. Every now and then someone comes into his office for paperwork or problems with the electricity, among other issues. He explains: "They bring all kinds of problems to me and we help as good as we can [...] And these cases are not yet marriage problems. There was for example a couple with marriage problems (...). Finally we brought a sheikh who helped them settle their dispute." ${ }^{65}$ Moreover the question of legal status papers requires counselling and advocacy: "Once, we called a lawyer to come to the camp in order to help with questions around the legal status [...]. We protect the people. This includes also that we find agreements with the authorities. Everybody is registered with the municipality and the police enters the camp only if someone is wanted." ${ }^{\prime 66}$ Also the community life within the camp is organised: a committee of eight members, who are part of the refugee community, takes care of needs and concerns of the camp residents. The committee members (lajne) are each responsible for a

\footnotetext{
${ }^{63}$ Field visit with conversations and interviews by the author, Bekaa Valley, 16 August 2016.

${ }^{64}$ URDA in Lebanon, "Productive villages projects," Online video, Youtube, 2 February 2016, available at: https://www.youtube.com/watch?v=vEUQRTr9kkg [last accessed 11 May 2017].

${ }^{65}$ Interview by the author with the camp's director, Bar Elias, 16 August 2017.

${ }^{66}$ Interview by the author with the camp's director, Bar Elias, 16 August 2017.
} 
part of the families. The families consult with him and he does some of the communication with the camp director.

Abu $\mathrm{Ziad}^{67}$ is one of the committee members. He is in his mid-forties and gives a tour at the camp and arranges meetings with other camp residents. Abu Hamza has lived for a year and a half with his wife and three school-aged children in al-Awda camp. Asked on the presence of journalists in the camp, Abu Hamza explains that he would be glad to talk to visitors, and that this would also be a nice opportunity for him to see Abu Ziad who is usually so busy with his shop and his work as a committee member. However, sometimes he finds it tiring when journalists come with the mentality that the refugees might all be terrorists because they come from this war in Syria. The social relations and the atmosphere at the camp are conspicuously friendly. While there have not been severe security incidents, Abu Hamza praises the fact that there are 50 cameras installed in the camp to monitor all the streets. "This is good for all of us. Like this we feel safe. My door is always open, I never lock it at night time." Asked if there are any specific rules or codes of conduct for the life in the camp, Abu Hamza answers that there are none, except for the basic rule to treat each other with mutual respect. While he and other camp residents expressed their appreciation of having found shelter in al-Awda productive village, they also expressed their wish to go back to Syria once the circumstances allow.

Matters in the camp appeared organised and functioning. The residents of Ar-Rahman camp and Al-Awda productive village who were presented by URDA as interviewee partners expressed their appreciation of the camps organisation and social structures. These would help them to engage positively in the community life and to bring back some sense of order and stability to their lives that were uprooted by the war in Syria. However, conversations during the camp visits were arranged by the URDA office and accompanied by an URDA employee or a committee member. Thus, it remains unclear how these camp structures leave room for dissent, a heterogeneous community life, and the criteria used to determine one's access to shelter. While not all of the Syrian refugee community may wish to live in such a conservative setting, many might find receiving charitable donations more acceptable if connected to moral religious values and communal solidarity, than along the equalising standards of humanitarian assistance by international organisations.

Despite URDA having successfully established working agreements with the local municipalities, the possibility that refugee camps could turn into permanent settlements and bring security risks remain a concern for the government. In autumn 2016, one of URDA's establishments, 'Al-Rihaniya Shelter Center' in the region of Bibneen, Akkar (North Lebanon), consisting of 300 tents was threatened to be closed. A security official from the region delivered word that the camp should be evacuated. A written order for the evacuation was not issued and the reasons were not specified any further, though security concerns were considered as likely. ${ }^{69}$ In response, URDA issued press releases, videos, and launched a

\footnotetext{
${ }^{67}$ Fictive name.

${ }^{68}$ See for further discussion on faith-based approaches in contexts of forced displacement: Elena

Fiddian-Qasmiyeh, "Introduction: Faith-Based Humanitarianism in Contexts of Forced Displacement," Journal of Refugee Studies, Oxford, Oxford University Press, 2011, Vol. 24 (3), p. 429-439.

${ }^{69}$ Caroline Akoum, "300 Syrian Families Asked to Evacuate North Lebanon Encampment," Asharq al-Awsat, 14
} 
Facebook page ("A Camp is Not a Threat"), a campaign which explained the situation and stressed that there is no security risk coming from the camp population consisting mainly of women, children, and elderly people and that the evacuation of the camp would cause a humanitarian emergency. ${ }^{70}$ The conflict seems to have been settled silently, as the camp is still mentioned among the different shelter sites on URDA's website and observers in the North report equally from the camp's continuity. The Facebook page has been removed and no follow-up press releases were published.

URDA representatives have repeatedly depicted the relations with the state's authorities as positive and cooperation as beneficial for the refugee population. For example, an URDA representative mentions cooperation with government authorities when URDA decided "to move in, not to keep standing at the sideline" when Syrian refugees "were trapped" between the fighting that had erupted between militant factions from Syria, mainly Da'esh and Jabhat al-Nusra, and the Lebanese Armed Forces in the Lebanese border town of Arsal in 2014 . $^{72}$ This underlines that despite the precarious security balance in the country, URDA is able to cooperate with the Lebanese Security Forces and has more flexibility than the UN to operate situations of conflict. While Gulf donors support multilateral agencies and therewith UNHCR-run refugee camps, they also run their own institutions and organisations on national and regional levels. Establishing their own institutions allows for "direct" deliveries to beneficiaries and URDA's shelter programmes, as well as alternative examples for the organisation and management of refugee camps and opportunities for bilateral cooperation with national governments and local stakeholders. In the meantime, however, the bypassing of the UN-led multilateral system and international humanitarian coordination structures raises questions in regard to hindrances and chances for better coordination.

\section{International Coordination of Humanitarian Assistance in Lebanon}

Coordination of humanitarian assistance aims to provide an overview of who is working in which areas to close protection gaps, bundle financial resources, and to operate efficiently. The Lebanese government, however, has not developed comprehensive coordination structures and leaves this to the different organisations working with Syrian refugees. ${ }^{73}$ In this situation, UNHCR has a lead in coordinating international NGOs and local partners.

\footnotetext{
November, 2016, available at:

http://english.aawsat.com/2016/11/article55362093/300-syrian-families-asked-evacuate-north-lebanon-encampm ent [last accessed 11 May 2017].

${ }^{70}$ URDA in Lebanon, "On the Request Notice to Evacuate Al-Rihaniya Shelter for Syrian Refugees," Beirut, URDA, 19 November 2016, available at: http://urda.org.lb/en/details.aspx?ID=1724 [last accessed 11 May 2017].

${ }^{71}$ Interview by the author, URDA office, Beirut, 2 August 2016.

${ }^{72}$ Lebanon Support, "Arsal Conflict (starting August 2, 2014)," Civil Society Knowledge Centre, 2015, available at: http://civilsociety-centre.org/security-timeline/arsal-conflict-starting-august-2-2014 [last accessed 11 March 2017].

${ }^{73}$ Karim El Mufti, op. cit.

${ }^{74}$ Dalya Mitri, "Challenges of Aid Coordination in a Complex Crisis: An Overview of Funding Policies and Conditions Regarding Aid Provision to Syrian Refugees in Lebanon," Civil Society Knowledge Centre, 2014, available at: http://civilsociety-centre.org/paper/challenges-aid-coordination-complex-crisis [last accessed 11 May 2017].
} 
Lebanese observers have repeatedly critiqued the UN-led crisis response for taking "ownership" of the crisis and for an unsatisfying inclusion of local stakeholders, for spending immorally high amounts of money on their administrations, and for the production of assessments and reports on matters that are evident for the people on the ground. ${ }^{75}$ The critique voiced by representatives from URDA, I'tilaf, and Islamic NGOs working in the Bekaa on humanitarian initiatives is similar. However, as they have their own funding sources and coordination mechanisms, they seem generally less bothered by questions of acknowledgment and funding barriers by the UN.

One of the aspects that representatives of Gulf-financed organisations present as their strengths is the presumably closer connections and engagement with the affected communities. The office director of one of URDAs member organisations in the Bekaa, al-Abrar Islamic Charitable Organisation, explains ${ }^{76}$ that his association has a network of volunteers who are connected to the communities and are quickly available to assist in supporting the communities. His organisation also sends the imam and camp school director to the nearby ar-Rahman camp. Volunteers at the camp include Syrian women who teach at the camp school. URDA's employment of camp directors from nearby villages supports the inclusion of local stakeholders and social cohesion. Nevertheless, a representative of one of I'tilaf's member organisations in the Bekaa Valley also expresses a lack of recognition when he reports how his organisation received the first refugees in Wadi Khaled (north Lebanon) in late 2011:

"We were working already before 2011 with the Lebanese population. When the refugees from Syria started to come, we were among the first to be there and we registered their names. Later UNHCR came and asked for the lists of beneficiaries and we gave it to them (...) but they didn't come back to work more with us.",77

The claim to be better connected to the affected communities through working on the ground, having volunteers, and taking religious orientation into consideration appears often to be discursively set against the formal and equalising standards of the UN-led international humanitarian system. Moreover, ad hoc deliveries from the Gulf States seem to expose the UN's lengthy bureaucratic restrictions and costs of administration procedures. URDA's director criticises: "UNHCR does not work on the ground, and does not know what the people really need. Moreover, UNHCR spends 30 to 40 percent of its funds on its own bureaucracy. We spend maximum 10 percent." "The actual spending on URDA's administrative costs is, however, hardly verifiable as the respective data is not public. Actors explain that fast and

\footnotetext{
${ }^{75}$ Leila Zakharia and Sonya Knox, "The International Aid Community and Local Actors: Experiences and Testimonies from the Ground," Civil Society Knowledge Centre, 2014, available at: http:/civilsociety-centre.org/paper/international-aid-community-and-local-actors-experiences-and-testimonies-gr ound [last accessed 11 May 2017]. See also: Susanne Schmelter, "The Question of Governing Syrian Refugees: An Ethnography of Lebanon's Humanitarian Regime," in Natalia Ribas-Mateos (ed.), Migration, Mobilities and the Arab Spring: Spaces of Refugee Flight in the Eastern Mediterranean, Northampton, Edward Elgar Publishing, 2016, p. 174-187.

${ }^{76}$ Interview by the author with the office director of Al Abrar Islamic Charitable Foundation in Chtaura, Bekaa Valley, 13 February 2014.

${ }^{77}$ Interview by the author with the office director of Ishrak Al Noor, Chtaura, Bekaa Valley, 13 February 2014.

${ }^{78}$ Cited in Susanne Schmelter and Ann-Kathrin Seidel, op. cit.
} 
non-bureaucratic delivery of humanitarian assistance may achieve immediate impact and reduce costs in the short-term. This was also reported from other emergency contexts; for example, during the reconstruction of Lebanon in 2006/2007, Gulf donors facilitated the building of a bridge while USAID was still busy completing an assessment for reconstructing the very same bridge.

Though the humanitarian funds from the Gulf are not only faster, they are less regular. This hinders refugees' abilities to rely on these distributions and for possible coordination partners to plan with certain deliveries. The al-Abrar office director, with the network of volunteers, concedes that these donations and distributions are not provided on a regular basis: "If we have something we go and deliver. If we have nothing, we don't go." ${ }^{80}$ Refugees in a "standard" (i.e. non-URDA-run) camp in the central Bekaa confirm this course of action. While they expressed a lot of confusion on how to access UN services, they said about Islamic associations: "Yes, they come too, but we don't know when and where." Such irregularities obstruct long-term planning and pose practical hindrances to cooperation. In 2014, the director of an Islamic, Bekaa-based NGO talked about the lack of coordination among the humanitarian actors in the crisis response and gave the example of a family who received four heaters (sobia), but no fuel. ${ }^{82}$ But while he said that they would like to cooperate more with the international system, he and his colleagues make equally clear that they are not willing to meet the UN-requirements for implementing partners, which they perceive as too bureaucratic and too focused on report-writing. He concluded that "the coordination with the UN refugee agency could be better; but the needs of the refugees from Syria are so huge, that we can virtually start everywhere." 83

However, the pressure on some of the Islamic and Gulf-backed organisations to enhance cooperation with UN-led interventions seems to have increased, as funding irregularities from the Gulf caused short-noted halts of on-going projects. Rapprochements to the international system seem to happen directly by applying for funds or indirectly by stressing the compatibility with international standards. In this sense, the interviewed URDA officials seem to perform a balancing act: on the one hand, they distinguish themselves as being ready to "step in" during critical situations, to "bridge gaps" by providing services, such as secondary health care, and "working around" government regulations in finding solutions for the precarious shelter situation of Syrian refugees in Lebanon. On the other hand, they highlight their adherence to international standards of professional assistance and neutrality as well as their cooperation with international NGOs and the UN. For example, an URDA official made clear: "We have procedures in place for everything, for proposals, project implementation and reporting. We do our budgetary planning for the period of one year." ${ }^{84}$ Projects with Oxfam

\footnotetext{
${ }^{79}$ Sultan Barakat and Steven Zyck, op. cit., p. 40; Andrea Binder and Claudia Meier, op. cit., p. 1135-1149.

${ }^{80}$ Interview by the author with the office director of Al Abrar Islamic Charitable Foundation in Chtaura, Bekaa

Valley, 13 February 2014.

${ }^{81}$ Camp visit by the author, Bekaa Valley, 31 January 2014.

${ }^{82}$ Interview by the author with director of local relief and development NGO, Chtaura, Bekaa Valley, 30 January 2014.

${ }^{83}$ Interview by the author with director of local relief and development NGO, Chtaura, Bekaa Valley, 30 January 2014.

${ }^{84}$ Interview by the author with URDA official, Beirut, 2 August 2016.
} 
were repeatedly mentioned as example for a cooperation partner, even though the majority of cooperating organisations come from the Gulf States. This, along with the insistence not to be described as an "Islamic" organisation - although the language used addresses a Sunni Syrian focal population - might be with an eye towards possible western funders and cooperation partners.

Occasional conversations with staff from the UN, non-Islamic NGOs, and international institutions suggest a rather rudimentary knowledge of the work of Islamic relief organisations in Lebanon: An UNHCR person responsible for Inter-Agency coordination explained, "There are internationally recognised principles for humanitarian aid such as neutrality and impartiality. This is for us a basic condition, which obstructs the collaboration with Islamic organisations." Additionally, a Lebanese academic working on relief mechanisms and coordination between the different humanitarian stakeholders in Lebanon, commented that it would be courageous to meet representatives of Islamic faith-based organisations in this area as they would mainly be extremists. ${ }^{86}$ Low standards of transparency and a lack of publicly available evaluations and reports make it indeed hard to exclude the diversion of funds from their proclaimed use. In this sense, the allegation of funding militant armed groups inside Syria has resulted in severe financial restrictions for I'tilaf. In 2016, I'tilaf's director stated that coordination with the UN is good, but that it basically does not go beyond avoiding the duplication of services. Despite risks of a supposed misuse of funds, organisations often seem to hide behind the alleged principles of neutrality and impartiality, as they sweepingly blame Islamic and Gulf-funded organisations of supporting terrorism. This, of course, is detrimental to exploring grounds for more coordination and cooperation. Given the high density of organisations working on the displacement in Lebanon and the remarkable outreach that Gulf-driven humanitarians organisations have, points of contact between the different humanitarian systems are so far surprisingly infrequent.

\section{Conclusion}

In the context of the Syrian emergency, the Gulf States channel parts of their humanitarian funds for the "Syria response" via international organisations such as the UN. At the same time, they support intermediate agencies such as I'tilaf and particularly URDA, along with their member associations. The trend of Gulf donors pursuing a double strategy, as they engage in both the international system and their own institutions on national and regional levels, is also observed on a more global scale.

The World Humanitarian Summit (WHS) in Istanbul in May 2016 was so far the largest event of its kind and intended to bring humanitarian stakeholders from different regions and

\footnotetext{
${ }^{85}$ Conversation by the author with UNHCR official for inter-agency coordination, Beirut, 21 March 2014.

${ }^{86}$ Conversation by the author with academic working on inter-agency coordination in Lebanon, 20 April 2014.

${ }^{87}$ Céline Billat, "The Funding of Humanitarian Action by the Gulf States: A Long-Term Commitment," Humanitarian Aid on the Move, Plaisians, URD, 2016, Vol. 17, p. 15-19, available at: http://www.urd.org/The-funding-of-humanitarian-action [last accessed 11 March 2017].
} 
political contexts together. ${ }^{88}$ As a result, the "great bargain" is intended to reduce bureaucratic red tape by harmonising reporting requirements, reducing management costs, giving more money directly to "frontline responders," and other assorted functions. The conveners of the different topics are almost exclusively of members of the Development Assistance Council (DAC). ${ }^{89}$ The summit was moreover an opportunity to exchange, and brought differences to light: representatives from DAC-countries showed interest in accessing the funds from the Gulf mobilised via the Zakat system, while showing little awareness of the approaches and traditions of Gulf-funded humanitarian assistance. ${ }^{90}$ In contrast, representatives from the Gulf States refuse to simply pay into the existing international system and rather demand acknowledgement of their traditions and approaches. ${ }^{91}$ Their strategic interest is not just directed to fitting in and meeting requirements but additionally to increasing independence, outreach, and leverage. The Gulf states partly refrain consciously from some international humanitarian and development coordination councils and use their own institutions, procedures and operational structures. By pursuing their specific initiatives, the Gulf-driven organisations expose much criticised aspects of the international humanitarian system, such as inflated bureaucratic requirements, high administrative costs, distance to the needs of the affected community, and imposing external dominance.

Yet, ad hoc deliveries with little administrative procedures and a lack of transparency make the Gulf donors also vulnerable to accusations of the misuse of funds and diminish accountability towards donors, beneficiaries, and possible cooperation partners. Irregularities in funding, less bureaucracy and presumably lower administrative costs open debates on how efficient these "direct" forms of assistance are in the long term. ${ }^{92}$ More long-term planning, reporting, supervision and evaluation mechanisms could increase the transparency and the visibility of their operations. This could effectively depict the operations' impact to the international humanitarian scene and provide grounds for enhanced cooperation with the UN-coordinated humanitarian system.

While I'tilaf had to deal with a drastic reduction of monetary funding accusations of channelling humanitarian funds to military activities in Syria, URDA has expanded quickly and is flourishing. Thereby, URDA seems to give more importance to expanding and promoting their programmes than to seeking the adherence to the pre-established operational procedures of the UN-coordinated emergency response. The expansion of URDA as a major service provider for Syrians displaced in Lebanon has been backed by a discourse that focuses

\footnotetext{
${ }^{88}$ Julia Steets and András Derzsi-Horváth, “Old Habits Die Hard at World Humanitarian Summit: Global Public Policy Institute,” Website, Global Public Policy Institute, 24 May 2016, available at:

http://www.gppi.net/publications/humanitarian-action/article/old-habits-die-hard-at-world-humanitarian-summit/ [last accessed 11 May 2017].

${ }^{89}$ Louise Redvers, "Hunting for the Grand Bargain," Website, IRIN News, 22 March 2017, available at: https://www.irinnews.org/analysis/2017/03/21/hunting-grand-bargain [last accessed 11 May 2017].

${ }^{90}$ Chloe Stirk, "An Act of Faith. Humanitarian Financing and Zakat," Global Humanitarian Assistance, Bristol, Development Intitatives, 2015, available at:

http://www.alnap.org/pool/files/dev-init-an-act-of-faith-march-2015.pdf [last accessed 11 May 2017].

${ }^{91}$ Elizabeth Dickinson, "In Crisis Zones, UN Courts Faith-Based Charities," Website, Devex, 6 July 2016, available at: https://www.devex.com/news/in-crisis-zones-un-courts-faith-based-charities-88260 [last accessed 11 May 2017].

${ }^{92}$ Andrea Binder, Claudia Meier, and Julia Steets, op. cit.

${ }^{93}$ Andrea Binder and Claudia Meier, op. cit.
} 
on "filling gaps," i.e. in service provision between the local and "the global" sphere and pursuing approaches that engage local communities. In bilaterally negotiating agreements with Lebanese state authorities, URDA has established itself as an independent humanitarian actor that navigates its position within Lebanon's sectarian power balance and clientelistic politics. Looking back to the visits at the URDA run camps, it appears that for a part of the refugee community and its adjacents, these shelter facilities provide more than stability, basic services, community life, and decent livelihood perspectives. They also provide order, security, and control. ${ }^{94}$ And while open questions remain in regard to funding and spending overviews as well as to possible political clientelism, URDA also advertises its compatibility to international standards of humanitarian service provision.

While humanitarian engagement of largely Gulf-financed organisations might even be seen as undermining the structures of the UN-led international humanitarian system, a wider perspective shows that it is actually a variety of factors that threaten and put current working modes of these international institutions into question. The rise of populism and nationalism in western societies is likely to come along with a reduced funding of international humanitarian institutions. ${ }^{95}$ International humanitarian action in Syria has shaken the humanitarian system's foundations of impartiality and neutrality and deeply questioned current operation modes. ${ }^{96}$ Academic studies moreover show that particularly in conflict environments, humanitarian action unfolds in close proximity to militaristic operations ${ }^{97}$ and that humanitarianism has also become an inherent part of the EU's border and migration regime. ${ }^{98}$ Jerôme Bellion-Jourdan describes the question if Islamic charities are actually humanitarian in view of the politicised contexts in which humanitarian operations take place as a wrong question (question piège). ${ }^{99}$ In view of all these underlying political dynamics, one might question to what extent the promotion of core principles such as neutrality and impartiality obstructs the view on basic structural circumstances, political matters, and in how far solidarity with those struggling with the circumstances of their displacement might actually be more appropriate in respect to their political subjectivity. Nevertheless, despite political differences and failures in living up to their own principles, multilateral institutions function also as instruments for conflict regulation and are supposed to mitigate the effects of political and military conflicts. The question, therefore, is how to create a multilateralism in

\footnotetext{
${ }^{94}$ Lebanon Support, "Crisis and Control. (In)Formal hybrid security in Lebanon," Civil Society Knowledge Centre, 2016, available at http://civilsociety-centre.org/resource/crisis-control-informal-hybrid-security-lebanon [last accessed 11 May 2017].

${ }^{95}$ Antonio Donini, "Humanitarianism at a Crossroads," Website, The Citizen, 12 May 2016, available at: http://www.thecitizen.co.tz/oped/Humanitarianism-at-a-crossroads/1840568-3475142-h7ri0uz/index.html [last accessed 11 May 2017].

${ }^{96}$ Julia Steets, "The Impasse in Syria Might Encourage Much Needed Changes in the Humanitarian System," Website, Professionals in Humanitarian Assistance and Protection (PHAP), 27 April 2014, available at: https://phap.org/thematic-notes/2014/april/impasse-syria-might-encourage-much-needed-changes humanitarian-system [last accessed 11 May 2017].

${ }^{97}$ Didier Fassin, La Raison Humanitaire: Une Histoire Morale Du Temps Présent, Paris, Gallimard, 2010.

${ }^{98}$ William Walters, "Foucault and Frontiers. Notes on the Birth of the Humanitarian Border," in Ulrich Bröckling, Susanne Krasmann, and Thomas Lemke (eds.), Governmentality: Current Issues and Future Challenges, London, Routledge, 2012, p. 138-164.

${ }^{99}$ Jérôme Bellion-Jourdan, "Les ONG Islamiques Sont-Elles Purement Humanitaires? Réflexions Sur Une Vraie Fausse Question," Vacarme, Paris, Association Vacarme, 2006, Vol. 34 (1), available at: http://www.vacarme.org/article558.html [last accessed 11 May 2017].
} 
humanitarian structures which is not necessarily dominated by western interests, but provides forums for the efficient coordination of relief mechanisms, for the promotion of commonly agreed international standards, and for mediating between conflicting positions.

So far, Gulf donors in Lebanon trigger a change of the humanitarian landscape that brings competition to the established structures of the international system. ${ }^{100}$ The competition between parallel humanitarian systems is likely to increase polarisation and a loss of overall capacity, but it also increases the variety of services and approaches. Studying these approaches closer might provide valuable impulses for reforms and appropriate inclusion of Gulf donors in the multilateral system. ${ }^{101}$ In this sense, the current fragmentation in the humanitarian landscape might be a good starting point to examine different approaches, reflect their effectiveness, and to acknowledge the existence of different stakeholders. Joint evaluation and increased cooperation could contribute to improving resource efficiency and better meeting the needs of those in need of humanitarian support. Moreover, it could counteract increasing polarisations and contribute to the regulation of future conflicts.

Lebanon has already been one of the crucial sites of reform initiatives within the UN system (e.g. cash programmes), but the country could play a much bigger role in exploring possible modes of cooperation between Gulf-funded relief mechanisms, the UN-coordinated response, and civil society. ${ }^{102}$ This is all the more true as the density of different humanitarian and development organisations is very high, and Lebanese society is not only formally very qualified but also practically very experienced in dealing with different factions, conflicting dynamics, with international organisations, flight, and migration.

This paper was first published in the 3 rd issue of the Civil Society Review.

\section{Bibliography}

Caroline Akoum, "300 Syrian Families Asked to Evacuate North Lebanon Encampment," Asharq al-Awsat, 14 November 2016, available at:

http://english.aawsat.com/2016/11/article55362093/300-syrian-families-asked-evacuate-north -lebanon-encampment [last accessed 11 March 2017].

Abd al-Rahman Arabi, “إخو ان’ لبنان ينتخبون مُرشدهم... الكلمة للشيو خ أم للشباب؟"Website, Alaraby, 20

\footnotetext{
${ }^{100}$ Ngaire Woods, "Whose Aid? Whose Influence? China, Emerging Donors and the Silent Revolution in Development Assistance," International Affairs, London, Chatham House, 2008, Vol. 84 (6) p. 1205-1221.

${ }^{101}$ Sultan Barakat and Steven Zyck, op. cit.; Ngaire Woods, op. cit.; Mohammed Kroessin and Abdulfatah Mohamed, op. cit.

${ }^{102}$ A suggestion for an according shift in this directions has for example been provided in: Rabih Shibli, "Reconfiguring Relief Mechanisms: The Syrian Refugee Crisis in Lebanon," Refugee Research and Policy in the Arab World Program, Beirut, Issam Fares Institute for Public Policy and International Affairs and UN Habitat, 2014, available at: https://www.aub.edu.lb/ifi/public_policy/pal_camps/Documents/research_reports/20140224ifi_pc_unrwa.pdf [last accessed 29 September 2017].
} 
December 2015, available at: https://www.alaraby.co.uk/politics/2015/12/19/

[last accessed 11 May 2017].

AUB and UN Habitat, "No Place to Stay? Reflections on the Syrian Refugee Shelter Policy in Lebanon," Beirut, American University of Beirut and UN Habitat, 2015, available at: https://www.aub.edu.lb/ifi/publications/Documents/research_reports/20150907_noplacetostay .pdf [last accessed 11 March 2017].

Sultan Barakat and Steven Zyck, "Gulf State Assistance to Conflict-Affected Environments," Kuwait Programme on Development, Governance and Globalisation in the Gulf States, York, The Centre for the Study of Global Governance, 2010, available at: http://eprints.lse.ac.uk/55240/ [last accessed 11 March 2017].

Leo Barasi, "Saudi Arabia's Humanitarian Aid a Political Takeover?", Humanitarian Exchange, London, Humanitarian Practice Network, 2005, Vol. 29, available at: http://odihpn.org/magazine/saudi-arabia\%C2\%92s-humanitarian-aid-a-political-takeover/ [last accessed 11 May 2017].

Jonathan Benthall and Jérôme Bellion-Jourdan, The Charitable Crescent: Politics of Aid in the Muslim World, New York, I.B. Tauris, 2003.

Jérôme Bellion-Jourdan, "Les ONG Islamiques Sont-Elles Purement Humanitaires? Réflexions Sur Une Vraie Fausse Question," Vacarme, Paris, Association Vacarme, 2006, Vol. 34 (1), available at: http://www.vacarme.org/article558.html [last accessed 11 May 2017].

Céline Billat, "The Funding of Humanitarian Action by the Gulf States: A Long-Term Commitment," Humanitarian Aid on the Move, Plaisians, URD, 2016, Vol. 17, p. 15-19, available at: http://www.urd.org/The-funding-of-humanitarian-action [last accessed 11 March 2017].

Andrea Binder, "Geben Ist Außenpolitik," Welternaehrung, Bonn, Zeitung Welthungerhilfe, 2014, available at:https://www.welthungerhilfe.de/fileadmin/user upload/Mediathek/Welternaehrung/Weltern aehrung-Zeitung-Welthungerhilfe-2-2014.pdf [last accessed 11 march 2017].

Andrea Binder and Claudia Meier, "Opportunity Knocks: Why Non-Western Donors Enter Humanitarianism and How to Make the Best of It," International Review of the Red Cross, Geneva, International Committee of the Red Cross and Cambridge University Press, 2011,Vol. 93 (884), p. 1135-1149.

Andrea Binder, Claudia Meier, and Julia Steets, "Humanitarian Assistance: Truly Universal? A Mapping Study of Non-Western Donors," Website, Global Public Policy Institute (GPPi), 2010, Vol.12, available at: http://www.gppi.net/fileadmin/media/pub/2010/Binder_Meier Steets 2010 Truly Univers al___Mapping_Study._GPPi_RP_12.pdf [last accessed 11 March 2011]. 
Melani Claire Cammett, Compassionate Communalism: Welfare and Sectarianism in Lebanon, Ithaca, Cornell University Press, 2014.

Estella Carpi, "Politics of Care and Social Responses in the July 2006 War: A Special Focus on Local Faith-Based Organisations," Civil Society Knowledge Centre, 2016, available at: http://civilsociety-centre.org/paper/politics-care-and-social-responses-july-2006-war-special-f ocus-local-faith-based-organisations [last accessed 11 March 2017].

Estella Carpi, “The Everyday Experience of Humanitarianism in Akkar Villages,” Civil Society Knowledge Centre, 2014, available at:

http://civilsociety-centre.org/paper/everyday-experience-humanitarianism-akkar-villages[last accessed 11 March 2017].

Development Initiatives, “Global Humanitarian Assistance Report 2016,” Bristol, Development Initiatives Ltd 2016, available at:

http://www.globalhumanitarianassistance.org/wp-content/uploads/2016/07/GHA-report-2016full-report.pdf [last accessed 11 March 2017].

Antonio Donini, "Humanitarianism at a Crossroads," The Citizen, 12 May 2016, available at: http://www.thecitizen.co.tz/oped/Humanitarianism-at-a-crossroads/1840568-3475142-h7ri0uz index.html [last accessed 11 March 2017].

Karim El Mufti, "Official Response to the Syrian Refugee Crisis in Lebanon, the Disastrous Policy of No-Policy," Beirut, Civil Society Knowledge Centre, 2014, available at: civilsociety-centre.org/paper/official-response-syrian-refugee-crisis-lebanon-disastrous-policy -no-policy [last accessed 11 March 2017].

Elena Fiddian-Qasmiyeh, "Introduction: Faith-Based Humanitarianism in Contexts of Forced Displacement," Journal of Refugee Studies, Oxford, Oxford University Press, 2011, Vol. 24 ( 3), p. 429-439.

Financial Tracking System, "Funding to Syrian Crisis 2015," Website, Financial Tracking System, 2015, available at:

https://ftsarchive.unocha.org/pageloader.aspx?page $=$ special-syriancrisis \&year $=2015$ [last accessed 11 May 2017].

Nathalie Fustier and Khalid al-Yahya, "Saudi Arabia as a Humanitarian Donor: High Potential, Little Institutionalization,” Berlin, Global Public Policy Institute, 2011, Vol. 14.

Abdel-Rahman Ghandour, "L'humanitaire Au Service de L'islam," Website, L'Express, 24 October 2002, available at:

http://www.lexpress.fr/culture/livre/l-humanitaire-au-service-de-l-islam 818277.html [last accessed 11 March 2017].

Christine Hamieh and Roger Mac Ginty, “A Very Political Reconstruction: Governance and 
Reconstruction in Lebanon after the 2006 War," Disasters, Hoboken, Wiley-Blackwell for the Overseas Development Institute, 2010, Vol. 34.

Mona Harb, "Faith-Based Organizations as Effective Development Partners? Hezbollah and Post-War Reconstruction in Lebanon," in Gerard Clarke and Michael Jennings (eds.), Development, Civil Society and Faith-Based Organizations, Basingstoke, Palgrave Macmillan, 2008, available at: http://link.springer.com/chapter/10.1057/9780230371262 10 [last accessed 11 March 2017].

Sarah Hasselbarth, Islamic Charities in the Syrian Context in Jordan and Lebanon, Beirut, Friedrich-Ebert-Stiftung, 2014.

Sabine Hess and Vassilis Tsianos, "Ethnographische Grenzregimeanalyse," in Sabine Hess and Bernd Kasparek (eds.), Grenzregime : Diskurse, Praktiken, Institutionen in Europa, Berlin, Assoziation A, 2010, p. 243-264.

International Crisis Group, "Hizbollah’s Syria Conundrum,” Middle East Report, Brussels, International Crisis Group, 2017, Vol. 175, available at:

https://d2071andvip0wj.cloudfront.net/175-hizbollah-s-syria-conundrum.pdf [last accessed 11 May 2017].

International Crisis Group, “Lebanon's Self-Defeating Survival Strategies," Middle East Report, Brussels, International Crisis Group, 2015, Vol. 160, available at: http://www.crisisgroup.org/en/regions/middle-east-north-africa/syria-lebanon/lebanon/160-leb anon-s-self-defeating-survival-strategies.aspx [last accessed 11 March 2017].

International Crisis Group, "Too Close for Comfort: Syrians in Lebanon," Middle East Report, Brussels, International Crisis Group, 2013, Vol. 141, available at: http://www.crisisgroup.org/en/regions/middle-east-north-africa/egypt-syria-lebanon/lebanon/1 41-too-close-for-comfort-syrians-in-lebanon.aspx [last accessed 11 March 2017].

Maja Janmyr, "The Legal Status of Syrian Refugees in Lebanon,” Working Papers, Beirut, Issam Fares Institute for Public Policy and International Affairs, 2016, available at: https://www.aub.edu.lb/ifi/publications/Documents/working_papers/20160331_Maja_Janmyr. pdf [last accessed 11 March 2017].

Bassam Khawaja, "Lebanon Policy Leaves 'Second-Class' Syrians Vulnerable to Return: HRW," Syria Deeply, 14 March 2017, available at: https://www.newsdeeply.com/syria/community/2017/03/14/lebanon-policy-leaves-second-cla ss-syrians-vulnerable-to-return-hrw-2 [last accessed 11 March 2017].

Gilles Kepel, Das Schwarzbuch des Dschihad: Aufstieg und Niedergang des Islamismus, München, Piper, 2002.

Mohammed Kroessin and Abdulfatah Mohamed, "Saudi Arabian NGOs in Somalia: 'Wahabi' Da'wah or Humanitarian Aid?", in Gerard Clarke and Michael Jennings (eds.) Development, 
Civil Society and Faith-Based Organizations, London, Palgrave Macmillan, 2008.

Lebanon Support, "Access to Healthcare for Syrian Refugees. The Impact of Fragmented Service Provision on Syrians' Daily Lives," Civil Society Knowledge Centre, 2016, available at:

http://civilsociety-centre.org/resource/access-healthcare-syrian-refugees-impact-fragmented-s ervice-provision-syrians\%E2\%80\%99-daily-lives [last accessed 11 May 2017].

Lebanon Support, “Arsal Conflict (starting August 2, 2014)," Civil Society Knowledge Centre, 2015, available at:

http://civilsociety-centre.org/security-timeline/arsal-conflict-starting-august-2-2014 [last accessed 11 March 2017].

Lebanon Support, "Crisis and Control. (In)Formal hybrid security in Lebanon," Civil Society Knowledge Centre, 2016, available at:

http://civilsociety-centre.org/resource/crisis-control-informal-hybrid-security-lebanon. [last accessed 11 March 2017].

Lebanon Support, "Formal Informality, Brokering Mechanisms, and Illegality. The Impact of the Lebanese State's Policies on Syrian Refugees' Daily Lives," Civil Society Knowledge Centre, 2016, available at:

http://civilsociety-centre.org/resource/formal-informality-brokering-mechanisms-and-illegalit y-impact-lebanese-state $\%$ E2\%80\%99s-policies [last accessed 11 March 2017].

Lebanon Support, "Politics of Care and Social Responses in the July 2006 War: A Special Focus on Local Faith-Based Organisations," Civil Society Knowledge Centre, 2016, available at:

http://civilsociety-centre.org/paper/politics-care-and-social-responses-july-2006-war-special-f ocus-local-faith-based-organisations [last accessed 11 March 2017].

Raphaël Lefèvre, “A New Direction for Lebanon's Muslim Brothers," Blog, Diwan Middle East Insights From Carnegie, 2 November 2016, available at:

http://carnegie-mec.org/diwan/62740?lang=en [last accessed 29 September 2019].

Raphaël Lefèvre, "Lebanon's Dar Al-Fatwa and the Search for Moderation,” Beirut, Carnegie Middle East Center, 2015, available at:

http://carnegie-mec.org/2015/01/05/lebanon-s-dar-al-fatwa-and-search-for-moderation-pub-57 627 [last accessed 11 May 2017].

Dalya Mitri, "Challenges of Aid Coordination in a Complex Crisis: An Overview of Funding Policies and Conditions Regarding Aid Provision to Syrian Refugees in Lebanon," Civil Society Knowledge Centre, 2014, available at: http://civilsociety-centre.org/paper/challenges-aid-coordination-complex-crisis [last accessed 11 May 2017].

Erik Mohns and André Bank, "Syrian Revolt Fallout: End of the Resistance Axis?”, Middle 
East Policy, Hoboken, Wiley-Blackwell, 2012, Vol. 19 (3), p. 15-25.

Hashem Osseiran, “Lebanon's Salafists Poised for Parliamentary Polls?”, Website, The Arab Weekly, 27 November 2016, available at:

http://www.thearabweekly.com//Opinion/7141/Lebanon's-Salafists-poised-for-parliamentarypolls? [last accessed 11 March 2017].

Louise Redvers, "Hunting for the Grand Bargain," Website, IRIN News, 22 March 2017, available at: https://www.irinnews.org/analysis/2017/03/21/hunting-grand-bargain [last accessed 11 March 2017].

Alain Robyns and Véronique de Geoffroy, Les Bailleurs Emergents de d'Aide Humanitaire. Le Cas des Pays du Golfe, Plaisians, Groupe URD, 2009, available at: http://www.urd.org/IMG/pdf/09 $10 \quad 10$ nouveaux bailleurs VF.pdf [last accessed 11 March 2017].

Stephan Rosiny, “A Quarter Century of 'Transitory Power-Sharing'. Lebanon's Unfulfilled Ta'if Agreement of 1989 Revisited," Civil Wars, 2015, Vol. 17 (4), p. 485-502.

Susanne Schmelter, "The Question of Governing Syrian Refugees: An Ethnography of Lebanon's Humanitarian Regime," in Natalia Ribas-Mateos (ed.), Migration, Mobilities and the Arab Spring: Spaces of Refugee Flight in the Eastern Mediterranean, Northampton, Edward Elgar Publishing, 2016, p. 174-187.

Susanne Schmelter and Ann-Kathrin Seidel, "Sanitäter Mit Scheckbuch," Zenith, Berlin, Deutscher Levante Verlag, 2015, p. 78-83.

Rabih Shibli, "Reconfiguring Relief Mechanisms: The Syrian Refugee Crisis in Lebanon," Refugee Research and Policy in the Arab World Program, Beirut, Issam Fares Institute for Public Policy and International Affairs and UN Habitat, 2014, available at: https://www.aub.edu.lb/ifi/public_policy/pal_camps/Documents/research_reports/20140224ifi _pc_unrwa.pdf [last accessed 29 September 2017].

Julia Steets and András Derzsi-Horváth, "Old Habits Die Hard at World Humanitarian Summit: Global Public Policy Institute,” Deutsche Welle, 24 May 2016, available at: http://www.gppi.net/publications/humanitarian-action/article/old-habits-die-hard-at-world-hu manitarian-summit/[last accessed 11 March 2017].

Chloe Stirk, "An Act of Faith. Humanitarian Financing and Zakat," Global Humanitarian Assistance, Bristol, Development Intitatives, 2015, available at:

http://www.alnap.org/pool/files/dev-init-an-act-of-faith-march-2015.pdf [last accessed 11 May 2017].

Lewis Turner, "Explaining the (Non-)Encampment of Syrian Refugees: Security, Class and the Labour Market in Lebanon and Jordan," Mediterranean Politics, London, Routledge, Taylor and Francis, 2015, Vol. 20 (3), p. 1-19. 
UNHCR, "Lebanon," Website, Syria Regional Refugee Response Inter-agency Information Sharing Portal, 30 June 2017, available at:

http://data.unhcr.org/syrianrefugees/country.php?id=122 [last accessed 11 March 2017].

URDA in Lebanon, "Annual Report of the Achievements of URDA - Lebanon. A Comprehensive Humanitarian Response," Beirut, URDA, 2015.

URDA in Lebanon, "Productive villages projects," Online video, Youtube, 2 February 2016, available at: https://www.youtube.com/watch?v=vEUQRTr9kkg [last accessed 11 May 2017].

URDA in Lebanon, "On the Request Notice to Evacuate Al-Rihaniya Shelter for Syrian Refugees," Beirut, URDA, 19 November 2016, available at:

http://urda.org.lb/en/details.aspx?ID=1724 [last accessed 11 May 2017].

William Walters, "Foucault and Frontiers. Notes on the Birth of the Humanitarian Border," in Ulrich Bröckling, Susanne Krasmann, and Thomas Lemke (eds.), Governmentality: Current Issues and Future Challenges, London, Routledge, 2012, p. 138-164.

Ngaire Woods, "Whose Aid? Whose Influence? China, Emerging Donors and the Silent Revolution in Development Assistance," International Affairs, London, Chatham House, 2008, Vol. 84 (6) p. 1205-1221.

Aaron Zelin, "Jihadism in Lebanon after the Syrian Uprising," in Maximilian Felsch and Martin Wählisch (eds.), Lebanon and the Arab Uprisings: In the Eye of the Hurricane, New York, Routledge, 2016, p. 50-69. 